\title{
Search and Rescue as an Enabler to Stimulate Cooperation in Areas of Tension
}

\author{
Erik Franckx*
}

In early August 2012, President Ma of the Republic of China (Taiwan) proposed an East China Sea peace initiative at the occasion of the 6oth anniversary of the coming into force of the Treaty of Peace between the Republic of China and Japan. His main proposal concerned a plea for cooperation on the exploration and exploitation of the resources in the area, but he also listed a few other areas by means of which the East China Sea could turn into a zone of peace and cooperation, one of them being search and rescue. ${ }^{2}$

The use of an agreement on search and rescue as vehicle for enhancing cooperation in the East China Sea, as proposed by President Ma, is certainly not new. Indeed, China and Japan had already started working on the conclusion of such an agreement. ${ }^{3}$ At a high level meeting between the Ministers of Foreign Affairs of both countries on 22 May 2011 both sides were in agreement that the work, which had apparently already been started, should be expedited in order to reach an early conclusion. ${ }^{4}$ When the Prime Ministers of both countries met in December 2011, it was stated that an agreement in principle had been

* The author would like to thank Mr. Wesley Lepla for the research assistance received while preparing this article.

1 Editors' Note: This article was selected from papers presented at two international conferences held in Hangzhou, China in 2012 and 2013, sponsored by the Centre for Ocean Law and Governance of Zhejiang University. The status of ratifications of treaties has not been updated and reflects the date of the conference to which it was submitted.

2 President Ma Proposes the East China Sea Peace Initiative, Taiwan In Depth, 5 August 2012, available at $\mathrm{http}: / /$ taiwanindepth.tw/ct.asp? xItem $=194468 \&$ CtNode $=1915$.

3 The idea to start negotiations on this topic was apparently taken in 2010. Overview of JapanChina Summit Meeting, Website of the Ministry of Foreign Affairs of Japan, 31 May 2010, available at http://www.mofa.go.jp/region/asia-paci/china/summit_meet1oo5.html.

4 Overview of the Japan-China Foreign Ministers' Meeting, Website of the Ministry of Foreign Affairs of Japan, 22 May 2011, available at http://www.mofa.go.jp/region/asia-paci/china/ sm1105.html. This was confirmed a few months later when both Ministers of Foreign Affairs met again. Overview of the Japan-China Foreign Ministers' Meeting, Website of the Ministry of Foreign Affairs of Japan, 4 July 2011, available at http://www.mofa.go.jp/region/asia-paci/ china/fmm1107.html.

(C) ERIK FRANCKX, 2019 | DOI:10.1163/9789004379633_013

This is an open access article distributed under the terms of the prevailing CC-BY-NC License at the time of publication. 
reached between the parties. ${ }^{5}$ When the rumor spread during the month of January 2012 that the conclusion of the agreement was imminent, the Japanese Chief Cabinet Secretary emphasized that discussions were still going on and that "some form of conclusion in the not too distant future" was to be expected, without however any precise deadline having been set. ${ }^{6}$

A few months later, moreover, at the occasion of the Fifth Trilateral Summit Meeting Among the People's Republic of China, the Republic of Korea and Japan a Joint Declaration on the Enhancement of Trilateral Comprehensive Cooperative Partnership was adopted in which the parties, in order to enhance political mutual trust, welcomed the recent agreement in principle reached between China and Japan, and reaffirmed ${ }^{7}$ the importance of enhancing cooperation in the field of search and rescue between the three parties. ${ }^{8}$

The above tour d'horizon clearly indicates that search and rescue cooperation has been on the agenda in the East China Sea for some time, either on a bilateral or trilateral basis. The present contribution intends to have a look at the manner in which cooperation in this field can enhance cooperation between States in this dispute prone region. After having defined the spatial extent of this study, the contemporary international legal framework governing search and rescue will be analyzed in general, followed by its application to the East China Sea more particularly. Based on a comparative approach with some other regions where search and rescue has been an issue between the parties, the final part will try to draw some conclusions for the East China Sea.

5 Japan-People's Republic of China Summit Meeting, Website of the Ministry of Foreign Affairs of Japan, 25 December 2011, available at http://www.mofa.go.jp/region/asia-paci/china/ meeting1112.html.

6 Press Conference by the Chief Cabinet Secretary, Website of the Prime Minister of Japan and His Cabinet, 11 January 2012, available at http://www.kantei.go.jp/foreign/tyoukanpress /201201/11_p.html.

7 During the previous summit, held on 22 May 2011 right after the serious earthquake in Japan, closer cooperation in this domain had already been envisaged. See Summit Declaration, Website of the Prime Minister of Japan and His Cabinet, 22 May 2011, available at http://www .kantei.go.jp/foreign/kan/statement/201105/22jcke.html. Such trilateral cooperation based on the establishment of bilateral mechanisms had already been addressed in 2008. Action Plan for Promoting Trilateral Cooperation among the People's Republic of China, Japan and the Republic of Korea, Website of the Ministry of Foreign Affairs of Japan, 13 December 2008, available at http://www.mofa.go.jp/region/asia-paci/jck/summito812/action.html.

8 The Fifth Trilateral Summit Meeting Among the People's Republic of China, the Republic of Korea and Japan: Joint Declaration on the Enhancement of Trilateral Comprehensive Cooperative Partnership, Website of the Prime Minister of Japan and His Cabinet, 13 May 2012, available at http://www.kantei.go.jp/foreign/noda/diplomatic/201205/13jck3_e .html. 
The focus of this article is on the East China Sea as defined by the International Hydrographic Organization in 1953 as Area 50. ${ }^{9}$ It should be noted in this respect that the specific nomenclature used in this publication to describe the sea area in question, namely "Eastern China Sea (Tung Hai)", ${ }^{10}$ has no juridical implications whatsoever as to the legal ownership of these water areas, ${ }^{11}$ irrespective of the multiple references to China it may contain..$^{12}$ The present contribution has therefore no difficulty in using this official nomenclature in a paper focusing on rules of international law applicable to this area, because the use of this nomenclature, no matter how widespread, can never on its own merits be relied upon in order to attribute to China any legal rights over this maritime expanse. ${ }^{13}$

9 International Hydrographic Organization, Limits of Oceans and Seas (Special Publication No. 28) 30-31 (1953), available at https://www.iho.int/iho_pubs/standard/S-23/S-23_ Ed3_1953_EN.pdf. The limits of Area 50 are defined as follows: "On the South. The Northern limit of the South China Sea (49), thence from Santyo the Northeastern point of Formosa to the West point of Yonakuni Island and thence to Haderuma Sima $\left(24^{\circ} 03^{\prime} \mathrm{N}, 123^{\circ} 47^{\prime} \mathrm{E}\right)$. On the East. From Haderuma Sima and thence to Okinan Kaku, the Southern extremity of Okinawa Sima, through this island to Ada-Ko Sima (Sidmouth Island) on to the East point of Kikai Sima $\left(28^{\circ} 20^{\prime} \mathrm{N}\right)$ through Tanegra Sima $\left(20^{\circ} 30^{\prime} \mathrm{N}\right)$ to the North point thereof and on to Hi-Saki $\left(31^{\circ} 17^{\prime} \mathrm{N}\right)$ in Kyusyu. On the North. From Nomo Saki $\left(32^{\circ} 35^{\prime} \mathrm{N}\right)$ in Kyusyu to the South point of Hukae Sima (Goto Retto) and on through this island to Ose Saki (Cape Goto) and to Hunan Kan, the South point of Saisyu To (Quelpart), through this island to its Western extreme and thence along the parallel of $33^{\circ} 17^{\prime}$ North to the mainland. On the West. The mainland of China".

10 Also Area 49 follows a similar pattern and is named "South China Sea (Nan Hai)". The only difference is that Area 50 has been labeled "Eastern" instead of "East". Because East China Sea is today the commonly used geographical name, this denomination has been preferred in the present contribution.

11 See more generally on this point, E. Franckx, M. Benatar, N. Joe, and K. Van den Bossche, The Naming of Maritime Features Viewed from an International Law Perspective, 11 CHINA Oceans LaW Review 1-40 (2011) [Chinese translation, ibid., at 41-69].

Such as the express reference to China in the denomination as well as the Chinese name in square brackets following it.

13 In this respect a further argument ex abundanti can be found in the express statement in the preface to the third edition of this $195^{2}$ publication, contained in its third paragraph, where it is stated that "[t]hese limits have no political significance whatsoever" (International Hydrographic Organization, supra note 9, at 2). Similar caveats are to be found on the accompanying maps (ibid., sheet 1-3, notes on top of the map in fine). Nevertheless, making such an argument with respect to the South China Sea denomination, see F. $\mathrm{Wu}$, Historical Evidence of China's Ownership of the Sovereignty over the Spratly Islands, in China Institute for Marine Development Strategy (ed.), Selected Papers of the Conference on the South China Sea Islands 111 (1992) [in Chinese], as mentioned by K. Zou, Historic Rights in International Law and in China's Practice, 32 Ocean Development and International LaW 149, 161 (2001) at note 98. 
The spatial extent of the East China Sea in other words corresponds grosso modo with the normal indication of this sea area on maps, excluding the Yellow Sea located to the North of it. The countries bordering this sea are consequently China, Japan and South Korea.

Taiwan, forming part of the southern boundary of Area 50, deserves special attention. Since its status as a State under contemporary international law is debated ${ }_{1}^{14}$ one could argue that it does not belong in the group of States bordering the East China Sea as defined above. On the other hand it cannot be denied that Taiwan has not only many ships in the area but also a developed Coast Guard Administration responsible for search and rescue. ${ }^{15}$ Not including Taiwan in a paper on search and rescue in the East China Sea would therefore seem rather odd. With respect to fisheries the international community has tackled this specific problem by introducing the new notion of "fishing entities". ${ }^{16}$ Even though the application of this new concept in practice is far from perfect, it has allowed Taiwan to become bound by certain multilateral treaty obligations with respect to fisheries, and sometimes even to draw rights from them. ${ }^{17}$ It is with these caveats in mind that the present contribution will include Taiwan in the discussion.

14 This is not the place to treat this issue in any detail. Suffice it to say that its status has been described as "a non-State territorial entity which is capable of acting independently on the international scene, but is most probably de jure part of China". See M. SHAw, International LAW 235 (2008). Taiwan is not a member of the United Nations, and the chances of it ever becoming a member are rather slim, as indicated by failed past attempts. As stressed by P. Malanczuk, Akehurst's Modern Introduction to INTERNATIONAL LAW, 372 (1997). Because many multilateral international conventions are only open to members of the United Nations, specialized agencies thereof, or States in general, Taiwan has not been able to become a party to most multilateral instruments relating to the law of the sea, unless specific provisions have been provided for to that extent in the agreements themselves.

15 See the official website of this administration, available at http://www.cga.gov.tw/Gip Open/wSite $/$ ct? xItem $=10850 \&$ ctNode $=1354 \& m p=$ eng $>$ ).

16 This denomination in itself is interesting, for in international law the notion of entity has been defined in the following manner: "Élément dont la qualification juridique est douteuse, non précisée - souvent à dessein - par le locuteur ou sur laquelle il ne veut pas se prononcer". J. Salmon, (ED.), Dictionnaire de droit international PUblic 432 (2001).

17 For a succinct overview with recommendations for improvement, see E. FrANCKX, FISHeries Enforcement. Related Legal and Institutional Issues: National, Subregional or Regional Perspectives 161-167 (2001), available at $<$ http://www .fao.org/3/Y2776E/y2776e.pdf>). See also A. Serdy, Bringing Taiwan into the International Fisheries Fold: The Legal Personality of a Fishing Entity, 75 British YeArboo of InterNATIONAL LAW 183-221 (2004). 
The duty to assist persons found at sea in danger of being lost stems from an old maritime tradition that already formed part of the early British Common Law, $^{18}$ a nation that, given its predominant interest in the formation of the law of the sea, believed that no new rule of international law could possibly emerge unless it was accepted by Great Britain. ${ }^{19}$

Belgium played a crucial role in the codification of this duty to render assistance. Even though the early attempts of the International Law Association ${ }^{20}$ to codify the whole international maritime law failed, ${ }^{21}$ it was through the $\mathrm{Co}_{\mathrm{O}}$ mité Maritime International, established in 1897 as a result of a purely Belgian initiative, ${ }^{22}$ that finally the Convention of Salvage was adopted in Brussels in 1910, in which the following provision was for the first time incorporated in an international legal instrument:

Every master is bound, so far as he can do so without serious danger to his vessel, her crew and her passengers, to render assistance to everybody, even though an enemy, found at sea in danger of being lost. The owner of a vessel incurs no liability by reason of contravention of the above provision. ${ }^{23}$

18 C.J. Colombos, The International Law of the Sea 345 (1967).

19 Ibid., at 10.

20 About the Belgian involvement in the establishment of the International Law Association, see for instance E. Franckx, De werkzaamheden van de International Law Association inzake marien milieurecht, in E. VAN HoOydonk (ED.), ZeEverontreiniging : PREVEnTIE, BESTRIJDING EN AANSPRAKELIJKHEID. 19, 22-23 (2004). See also by the same author in English: The Work of the ILA Committee on Coastal State Jurisdiction Relating to Marine Pollution and Its Implications for the Aegean Sea, in B. ÖTZtÜr,, (ED.), ThE AEgEAN SEA 2000 221, 221-222 (2000) and The ILA Survey on Coastal State Jurisdiction with Special Reference to Regional Rules, in H. Ring bom (ED.), COMPETING Norms in the LAW of Marine Environmental Protection 59, 6o-61 (1997).

21 Two conferences, sponsored by the Belgian government, were held in 1885 (Antwerp) and 1888 (Brussels). They failed however in their main objective.

22 As described in some detail in the historical section of the website of the Comité Maritime International, available at http://comitemaritime.org/History/o,273,1332,0o.html.

23 Convention for the Unification of Certain Rules of Law respecting Assistance and Salvage at Sea, signed on 23 September 1910 (entered into force 1 March 1913), Art. 11, available at http://www.admiraltylawguide.com/conven/salvage1910.html. This is an English translation of the original French text, which reads:

Tout capitaine est tenu, autant qu'il peut le faire sans danger sérieux pour son navire, son équipage, ses passagers, de prêter assistance à toute personne, même ennemie, trouvée en mer en danger de se perdre. Le propriétaire du navire n'est pas responsable à raison des contraventions à la disposition précédente. 
Even though this convention did not stand the test of time, mainly because of its lack to take into consideration environmental concerns, the duty to assist persons found at sea in danger of being lost substantially remained unchanged in the follow-up convention ${ }^{24}$ adopted this time under the auspices of the International Maritime Organization. ${ }^{25}$ In the meantime, this obligation had also been incorporated in the Convention on the High Seas ${ }^{26}$ and the so-called solas Convention. ${ }^{27}$ At present, this rule also forms part of the Constitution for the Oceans, i.e. the United Nations Convention on the Law of the Sea, and reads as follows:

Every State shall require the master of a ship flying its flag, in so far as he can do so without serious danger to the ship, the crew or the passengers:

(a) to render assistance to any person found at sea in danger of being lost;

(b) to proceed with all possible speed to the rescue of persons in distress, if informed of their need of assistance, in so far as such action may reasonably be expected of him;

(c) after a collision, to render assistance to the other ship, its crew and its passengers and, where possible, to inform the other ship of the name of his own ship, its port of registry and the nearest port at which it will call. ${ }^{28}$

24 International Convention on Salvage, signed on 28 April 1989, 1953 UNTS 193 (entered into force 14 July 1996), Art. 10, available at http://www.admiraltylawguide.com/conven/ salvage1989.html. Hereinafter, 1989 Salvage Convention. The article now counts three paragraphs:

1. Every master is bound, so far as he can do so without serious danger to his vessel and persons thereon, to render assistance to any person in danger of being lost at sea.

2. The States Parties shall adopt the measures necessary to enforce the duty set out in paragraph 1.

3. The owner of the vessel shall incur no liability for a breach of the duty of the master under paragraph 1.

25 The Inter-Governmental Maritime Consultative Organization, as it was originally called, was established in 1948. In 1982 the name of the organization was changed into International Maritime Organization. Hereinafter, Iмо.

26 Convention on the High Seas, signed on 29 April 1958, 450 UNTS 11 (entered into force 30 September 1962), Art. 12, available at untreaty.un.org/ilc/texts/instruments/english/con ventions/8_1_1958_high_seas.pdf.

27 Convention for the Safety of Life at Sea, signed on 1 November 1974, 1184 UNTS 277-453 (entered into force 25 May 1980), Chapter v, Regulation 10, available at http://www.austlii .edu.au/au/other/dfat/treaties/1983/22.html. Hereinafter, 1974 SOLAs Convention.

28 United Nations Convention on the Law of the Sea, signed on 10 December 1982, 1833 UNTS 397 (entered into force 16 November 1994), Art. 98, para. 1, available at http://www.un.org/ Depts/los/convention_agreements/texts/unclos/unclos_e.pdf. Hereinafter, 1982 Convention. It should be noted that the $195^{8}$ Convention on the High Seas (supra note 26 ) and 
But, as has been stressed in the legal literature, the obligation to render assistance should be distinguished from the obligation to rescue. ${ }^{29}$ The former is a notion which has been purposefully kept vague in the different instruments leaving sufficient leeway to the master of the ship to fulfil this obligation. ${ }^{30}$ The latter is an obligation only imposed on States and has been defined in a much more detailed way as will be demonstrated below.

The legal framework of search and rescue operations has to be found mainly in two international conventions. In chronological order they are the International Convention on Maritime Search and Rescue, adopted under the auspices of the IMO in $1979,{ }^{31}$ and the 1982 Convention. Both documents will be addressed in turn.

\section{A}

1979 SAR Convention

The 1979 SAR Convention was the first international legal instrument dealing with the subject matter in any detail..$^{32}$ At present there are 103 States parties

the 1982 Convention, contrary to most other legal documents mentioned in this respect above, do not attribute the obligation to render assistance directly to the master of the ship, but only indirectly though the flag State, which in turn must require the master of the vessel to act according to the obligation. The ultimate bearer of the obligation, nevertheless, always remains the master of the ship. The 1989 Salvage Convention is special in that it combines both approaches (supra note 24) because it places the main obligation on the master of the ship and reinforces it by requiring the State parties to adopt the necessary measures to enforce that obligation resting on the master of the vessel.

29 F.J. Kenney, and V. Tasikas, The Tampa Incident: IMO Perspectives and Responses on the Treatment of Persons Rescued at Sea, 12 Pacific Rim Law And Policy Journal 143, 151-159 (2003).

$30 \quad$ Ibid., at $15^{1-152 .}$

31 International Convention on Maritime Search and Rescue, 27 April 1979, 1985 UNTS 118 (entered into force 22 June 1985), available at http://www.admiraltylawguide.com/con ven/searchrescue1979.html; 2004 amendments available at http://www.navcen.uscg.gov/ pdf/marcomms/imo/msc_resolutions/MSC155(78).pdf. Hereinafter, 1979 SAR Convention.

The general obligation for States to maintain adequate search and rescue services along their coasts was already to be found in the predecessor of the 1974 Solas Convention (supra note 27), namely the Convention for the Safety of Life at Sea, signed on 10 June 1948, 164 UNTS 113 (entered into force 19 November 1952), Chapter 5, Regulation 15, available at http://www.imo.org/KnowledgeCentre/ReferencesAndArchives/HistoryofSOLAS/ Documents/SOLAS\%201948\%20UK\%2oTreaty\%20Series.pdf. This regulation reads:

(a) Each Contracting Government undertakes to ensure that any necessary arrangements are made for coast watching and for the rescue of persons in distress at sea round its coasts. These arrangements should include the establishment, operation and maintenance of such maritime safety facilities as are deemed practicable and necessary having regard to the density of the seagoing traffic and the navigational dangers and should, so far as possible, afford adequate means of locating and rescuing such persons. 
to the convention representing about 62.45 percent of the gross tonnage of the world's merchant shipping. ${ }^{33}$ The convention itself is very short, consisting of only eight articles, of which six moreover concern the so-called final clauses of international agreements, namely those provisions dealing with amendments, the manner to become a party, entry into force, denunciation, deposit and registration, and languages. There is only one substantial article entitled "General Obligations Under the Convention", stating: "The Parties undertake to adopt all legislative or other appropriate measures necessary to give full effect to the Convention and its Annex, which is an integral part of the convention. Unless expressly provided otherwise, a reference to the Convention constitutes at the same time a reference to its Annex". ${ }^{34}$

The remaining provision, Article 2, has to do with the particular timeframe in which this convention has been negotiated, namely at the time that the law of the sea was being completely overhauled by means of the Third United Nations Conference on the Law of the Sea (1973-1982). It represents a standard clause which was often literally, or at least substantially, reproduced in many other agreements that touch upon law of the sea issues and that were concluded during this period of high uncertainty, which characterized this specific branch of international law at that time. ${ }^{35}$

The essence of the legal obligations of this convention is therefore to be found in the Annex attached to the Convention. Each State party is obligated to ensure that adequate search and rescue services are available in its coastal waters. ${ }^{36}$ State parties are moreover encouraged to enter into search and rescue agreements with neighboring countries in the region. ${ }^{37}$ After the adoption

(b) Each Contracting Government undertakes to make available information concerning its existing rescue facilities and the plans for changes therein, if any.

International Maritime Organization, International Convention on Search and Rescue, 1979, as Amended: Accession by Indonesia, IMO Doc. SAR.1/Circ.91, 30 August 2012, available at http://www.imo.org/OurWork/Circulars/Pages/IMODOCS.aspx.

341979 SAR Convention, supra note 31, Article 1.

35 Art. 2 reads as follows: "1) Nothing in the Convention shall prejudice the codification and development of the law of the sea by the United Nations Conference on the Law of the Sea convened pursuant to resolution $2750(\mathrm{xxv})$ of the General Assembly of the United Nations nor the present or future claims and legal views of any State concerning the law of the sea and the nature and extent of coastal and flag State jurisdiction. 2) No provision of the Convention shall be construed as prejudicing obligations or rights of vessels provided for in other international instruments". For a more elaborate analysis of this particular clause, see Erik Franckx, the Relationship Between Cites, Fao and Related Agreements: Legal Issues, Rome, Food and Agriculture Organization 29-35 (2011), available at http://www.fao.org/docrep/o13/i1976e/i1976eoo.pdf.

$36 \quad 1979$ SAR Convention, supra note 31, Annex, 2.1.1.

37 Ibid., Annex, 2.1.3 to 2.1.6. 
of the convention, the Maritime Safety Committee of the IMO divided the world into thirteen search and rescue areas. ${ }^{38}$

In these annexes one can also find for the first time a detailed definition of what has to be understood by search, namely "[a]n operation, normally coordinated by a rescue coordination center or rescue sub center, using available personnel and facilities to locate persons in distress", and rescue, namely "[a]n operation to retrieve persons in distress, provide for their initial medical or other needs, and deliver them to a place of safety". ${ }^{39}$ The latter is not normally the ship rendering assistance. ${ }^{40}$

It has therefore been argued that if the duty to render assistance is required of the shipmaster, ${ }^{41}$ the obligation to rescue rests only with the State. ${ }^{42}$

38 Information available at http://www.imo.org/about/conventions/listofconventions/ pages/international-convention-on-maritime-search-and-rescue-(sar).aspx. Because the convention initially had difficulty in ensuring a sufficient amount of ratifications, a revised Annex was consequently adopted in 1998. A second amendment was adopted in 2004 in order to specify in some more detail the notions of "persons in distress" and "places of safety" (ibid.). This second amendment was a direct result of the $M / V$ Tampa incident of 2001, when Australia refused the disembarkation of more than 400 persons rescued from a sinking Indonesian ferry. K. Gustafson Juras, J.E. Noyes, and E. Franckx, LaW of the Sea in a Nutshell 41-42 (2010) and D.R. RothWell and T. Stephens, The International LaW of the SeA 162 (2010). The present analysis is based on the text of the 1979 SAR Convention including both amendments, which entered into force in January 2000 and July 2006 respectively.

391979 SAR Convention, supra note 31, Annex, 1.3.1 and 1.3.2.

40 Ibid., Annex, 3.1.9, which reads: "Parties shall coordinate and cooperate to ensure that masters of ships providing assistance by embarking persons in distress at sea are released from their obligations with minimum further deviation from the ships' intended voyage, provided that releasing the master of the ship from these obligations does not further endanger the safety of life at sea. The Party responsible for the search and rescue region in which such assistance is rendered shall exercise primary responsibility for ensuring such coordination and cooperation occurs, so that survivors assisted are disembarked from the assisting ship and delivered to a place of safety, taking into account the particular circumstances of the case and guidelines developed by the Organization. In these cases, the relevant Parties shall arrange for such disembarkation to be effected as soon as reasonably practicable".

41 As indicated supra note 28 , it is only the enforcement of compliance with this duty to render assistance that can be delegated to States. See also M. Davies, Obligations and Implications for Ships Encountering Persons in Need of Assistance at Sea, 12 PACIFIC RIM LAW AND Policy Journal 109, 141 (2003).

42 Kenney \& Tasikas, supra note 29, at 157. According to these authors only Art. 98, para. 1 , sub b of the 1982 Convention (as reproduced supra note 28 and accompanying text) does at first sight not seem to follow this logic, unless one reads into "in so far as such action may be reasonably expected of them" the hypothesis that the vessel rendering assistance is exceptionally to be considered a "place of safety" (supra notes 39-40 and accompanying text). 
The purpose of the drafters of the 1982 Convention was not to replace all pre-existing international conventions relating to the law of the sea. On the contrary, the 1982 Convention only deals with the general rules determining competences but leaves all technicalities to the relevant conventions already existing or still to be elaborated. ${ }^{43}$ Even though the 1982 Convention, which is a document largely adhered to by the international community, ${ }^{44}$ does touch upon the issue of search and rescue, it only states the general principle:

Every coastal State shall promote the establishment, operation and maintenance of an adequate and effective search and rescue service regarding safety on and over the sea and, where circumstances so require, by way of mutual regional arrangements cooperate with neighbouring States for this purpose. ${ }^{45}$

The details of the search and rescue regime, therefore, are still governed in essence by the 1979 SAR Convention today. ${ }^{46}$

\section{Application to the East China Sea}

In order to fully appreciate the application of the above-mentioned legal framework to the East China Sea, one has of course first to ascertain the manner in which the countries surrounding this area have been willing to subscribe to the relevant international legal instruments just mentioned. As indicated in Table 1, with the exception of Taiwan for obvious reasons explained above, all countries are a party to both documents. This stands in contrast to the South

43 C. Douay, Le droit de la mer et la préservation du milieu marin, in: DANIEL BARDONNET and Michel Virally (eds.), Le nouveau droit international de la mer 231, $248(1983)$.

44 At present 163 States and the European Union are legally bound by this international instrument.

451982 Convention, supra note 28 , Art. 98 , para. 2. This particular provision of the 1982 Convention moreover does not excel in clarity for it combines the words "promote", which seems to allow the coastal state a large margin of flexibility, with the words "adequate and effective", which on the other hand seem to restrict the leeway granted to that same State. For a detailed analysis, see A.E. Moen, For Those in Peril on the Sea: Search and Rescue under the Law of the Sea Convention, 24 OCEAN YeArbooK 377, 384-403 (2010).

46 Stressing this more specific nature of the 1979 SAR Convention when compared to the 1982 Convention and the 1974 Solas Convention, see International Maritime Organization, Implications of the United Nations Convention on the Law of the Sea for the International Maritime Organization, IMO Doc. LEG/MISC.7, 19 January 2012, at 38. 
TABLE 1 Status of Ratification

\begin{tabular}{lllll}
\hline & 1982 Convention & & \multicolumn{2}{c}{ 1979 SAR Convention } \\
& Signature & Ratification & Signature & Ratification \\
China & 10 December 1982 & 7 June 1996 & 24 June 1985 & 24 June 1985 \\
Japan & 7 February 1983 & 20 June 1996 & 10 June 1985 & 22 June 1985 \\
South Korea & & 29 January & 4 September & 4 October \\
& 14 March 1983 & 1996 & 1995 & 1995 \\
Taiwan & / b & / b & /c & /c \\
\hline
\end{tabular}

a Applies to the Hong Kong Special Administrative Region with effect from 1 July 1997 and to the Macao Special Administrative Region with effect from 24 June 2005.

b Excluded from becoming a party according to Article 305 (1) of the 1982 Convention.

c Excluded from becoming a party according to Article 4 (1) of the 1979 SAR Convention.

China Sea where until recently the majority of coastal States were not a party to the 1979 SAR Convention. ${ }^{47}$ Moreover, the countries in the East China Sea signed and ratified these two conventions at around the same time, with the exception of South Korea with respect to the 1979 SAR Convention, which only did so a decade after China and Japan.

The East China Sea forms part of the North-West Pacific search and rescue area as determined by the IMO ${ }^{48}$ where search and rescue operations are conducted by China, the Democratic People's Republic of Korea, Japan, the Philippines, the Republic of Korea and the Russian Federation. As stated in a note under this particular search and rescue area, however, "Areas of responsibility have not yet been defined by the above States. However, each country in the area has undertaken, on receipt of a distress alert, to ensure that action will be taken to coordinate [search and rescue] in the most expeditious manner". ${ }^{49}$

On the same map it is moreover indicated that Japan has limited the area for which this country is responsible as far as search and rescue is concerned in the east and the south by a line connecting the coordinates $52^{\circ} 30^{\prime} \mathrm{N} / 165^{\circ}$

47 As stressed by S. Bateman, Good Order at Sea in the South China Sea, in S. Wu, AND K. Zou (eds.), Maritime Security in the South China Sea: Regional Implications And International Cooperation 15, 21 and the table on 23 (2009). Since then, the convention has also entered into force for Indonesia on 23 September 2012. International Maritime Organization, International Convention on Maritime Search and Rescue, 1979, as Amended: Accession by Indonesia, IMO Doc. SAR.1/Circ.91, 30 August 2012, available at http://www.imo.org/OurWork/Circulars/Pages/IMODOCS.aspx.

48 See supra note 38 and accompanying text.

49 Information available at http://www.oceansatlas.com/unatlas/issues/emergencies/gmd ss_sar/SARMAP.PDF. 
$\mathrm{E}, 17^{\circ} \mathrm{N} / 165^{\circ} \mathrm{E}$, and $17^{\circ} \mathrm{N} / 130^{\circ} \mathrm{E}$. Because this line is totally located outside the East China Sea, the latter is rather covered by the last sentence of the same note on the map, which states that the search and rescue region of Japan is subject to bilateral discussions with the countries involved. ${ }^{50}$

Because this article is limited to the East China Sea, the following supplementary information can be added concerning that region proper. Japan has established 11 Maritime Rescue Coordination Centers, of which primarily two are responsible for the East China Sea region, namely the one located in Kagoshima, responsible for the Kagoshima area, and the other in Naha, responsible for the Okinawa area. ${ }^{51}$ China has a central Center in Beijing, but also 18 associated coast radio stations. ${ }^{52}$ Of the latter four are mainly responsible for the East China Sea as defined above, namely Fuzhou, Ningbo, Shanghai and Wenzhou. ${ }^{53}$ The Republic of Korea, finally, had initially five main Maritime Rescue Coordination Centers, each of which had two sub Centers except for the Jeju Maritime Rescue Coordination Center, which had none. It was this last Center that was mainly responsible for the East China Sea. ${ }^{54}$ However, in 2010 this country rearranged its Rescue Coordination Centers with the Jeju Rescue Coordination Center receiving a Rescue Sub Center, namely Seowipo

\section{$50 \quad$ Ibid}

51 Japan submitted its search and rescue plan in 2005. See International Maritime Organization, Global SAR Plan Containing Information on the Current Availability of SAR Services, IMO Doc. SAR.8/Circ.1/Corr.3, 20 October 2005, at 11-22, available at http://www5.imo. org/SharePoint/blastDataHelper.asp?data_id=166o8\&filename=1-Corr-3.pdf. The corrections introduced by this country in 2010 do not change this basic structure. International Maritime Organization, Availability of Search and Rescue (SAR) Services, IMO Doc. SAR.8/ Circ.3, 17 June 2011, at 160-172, available at http://www.imo.org/OurWork/Circulars/Pages /IMODOCS.aspx. Hereinafter, SAR.8/Circ.3.

$5^{2}$ For a description of the Chinese search and rescue structure, see for instance S. Hao, Maritime Aspects of China's Humanitarian Operations Policy, in A.S. ERICKSON, Goldstein, and N. Li (Eds.), China, the United States and 21St Century Sea Power: Defining A Maritime Security Partnership 236-251 (2010) and J. Zhang, Commentary: Search and Rescue in the South China Sea and Regional Cooperation, in Maritime Security in the South China Sea: Regional Implications and INTERNATIONAL COOPERATION, supra note 47 , at $255^{-261}$.

53 China submitted its search and rescue plan in 2006. International Maritime Organization, Global SAR Plan Containing Information on the Current Availability of SAR Services, IMO Doc. SAR.8/Circ.1/Corr.4, 21 April 2006, at 6-7, available at http://www5.imo.org/Share Point/blastDataHelper.asp?data_id=14518\&filename=1-Corr-4.pdf. Hereinafter, SAR.8/ Circ.1/Corr.4. This plan has not been substantially changed since then. Compare with SAR.8/Circ.3, supra note 51 , at $58-59$.

54 The Republic of Korea submitted its search and rescue plan in 2006. SAR.8/Circ.1/Corr.4, supra note 53 , at $39-41$. 
on the southern part of the island Jeju facing the East China Sea. ${ }^{55}$ The Republic of Korea is moreover the only country giving the exact limits of the areas for which each of the five main Centers is responsible. For the Jeju Center this zone covers about the northwestern part of the East China Sea starting from $30^{\circ} \mathrm{N}$ in the south. ${ }^{56}$ Since it covers that area in the east up to the Chinese mainland, a note adds that foreign territorial waters lying on the inside of the polygon are to be excluded. ${ }^{57}$ It is to be noted that the northeastern part of the East China Sea is not covered in a similar way up to the coast of Japan, but rather splits the area roughly in two. ${ }^{58}$

In this far from perfect framework, the parties have felt the need to start cooperating in the field, i.e. by organizing joint search and rescue activities in the East China Sea. By way of examples, mention can be made of the 1999 joint operation between Japan and South Korea ${ }^{59}$ or the joint exercise held between

55 There are still five Rescue Coordination Centers, of which two are new. The two that were replaced form part today of the 12 Rescue Sub Centers. SAR.8/Circ.3, supra note 51, at 239-242. Jeju, the capital of Jeju Island, faces the Korean peninsula.

$5^{6}$ SAR.8/Circ.1/Corr.4, supra note 53, at 41. The area is a polygon of which the outer boundary is determined by a line connecting the following nine points: a) $34^{\circ} 00^{\prime} \mathrm{oo} \mathrm{N} \mathrm{N} / 126^{\circ}$ $15^{\prime}$ oo" E; b) $34^{\circ}$ oo' oo" N / $127^{\circ}$ oo' oo" E; c) $33^{\circ} 15^{\prime}$ oo" N / $128^{\circ}$ oo' oo" E; d) $33^{\circ} 12^{\prime}$ oo" N / $128^{\circ}$ o5' oo" E; e) $32^{\circ} 30^{\prime}$ oo" N / $127^{\circ} 30^{\prime}$ oo" E; f) $30^{\circ}$ oo' oo" N / $125^{\circ} 25^{\prime}$ oo" E; g) $30^{\circ}$ oo' oo" $\mathrm{N} / 121^{\circ}$ oo' oo" E; h) $32^{\circ} 14^{\prime}$ oo" N / $121^{\circ}$ oo' oo" E; and i) $34^{\circ} 0^{\circ}$ oo" N / $126^{\circ} 15^{\prime}$ oo" E. This polygon was slightly changed in 2010 with the addition of two more points, namely: a) $34^{\circ}$ oo' oo" N / $126^{\circ} 15^{\prime}$ oo" E; b) $34^{\circ}$ oo' oo" N / $126^{\circ}$ oo' oo" E; c) $33^{\circ} 56^{\prime}$ oo" N / $126^{\circ} 30^{\prime}$ oo" E; d) $33^{\circ} 56^{\prime}$ oo" N / $127^{\circ} 13^{\prime} 30^{\prime \prime} \mathrm{E}$; e) $33^{\circ} 15^{\prime}$ oo" N / $128^{\circ}$ oo' oo" E; f) $33^{\circ} 12^{\prime}$ oo" N / $128^{\circ} 05^{\prime}$ oo" E; g) $32^{\circ} 30^{\prime}$ oo" N / $127^{\circ} 30^{\prime}$ oo" E; h) $30^{\circ}$ oo' oo" N / $125^{\circ}$ oo' oo" E; i) $30^{\circ} 00^{\prime}$ oo" N / $121^{\circ} 00^{\prime}$ oo" E; j) $32^{\circ} 14^{\prime}$ oo" N / $121^{\circ}$ oo' oo" E; k) 34 oo' oo" N / $126^{\circ} 15^{\prime}$ oo" E. See SAR.8/Circ.3, supra note 51 , at 242 . The part south of Seju Island, however, remained largely unchanged. The northeastern part of the polygon only reaches up to parallel $32^{\circ} 14^{\prime} \mathrm{N}$, meaning that the area up to parallel $33^{\circ} 17^{\prime} \mathrm{N}$, i.e. the northern boundary of the East China Sea as defined for present purposes (see supra note 9) is not covered by the Jeju Coordination Center. In 2006 this zone was instead covered by the Mokpo Maritime Rescue Coordination Center, but after the changes introduced in 2010 this particular area appears no longer to be covered.

57 SAR.8/Circ.3, supra note 51, at 242. By means of the changes introduced in 2011 a new Rescue Coordination Center was established at Namhae, the field of operation of which covers the same area south of Seju already covered by the Seju Rescue Coordination Center. A note under the limits of the Namhae Center, however, reads "the area except for foreign territorial water and Jeju within a line connecting the above points".

58 See attached map in Annex 1.

59 M.J.Valencia, Conclusions and Lessons Learned, in M.J. Valencia (ed.), Maritime Regime Building: Lessons Learned and Their Relevance for Northeast Asia 149, 165 (2001). 
the Chinese Shanghai and the Japanese Kagoshima Center. ${ }^{60}$ This kind of cooperation seems to have been increasing over the years. ${ }^{61}$

It will be clear from the above analysis that the present-day unilateral implementation of the search and rescue obligations in the East China Sea under the 1979 SAR Convention is in urgent need of coordination by the coastal States. As the situation now stands, it is easily imaginable that this situation may at any time raise the tension instead of diminishing it. It should not be forgotten that the whole 1995 Imia/Kardak crisis in the Aegean Sea ${ }^{62}$ started as a search and rescue incident, where the captain of a Turkish vessel in difficulty contested the competence of Greek vessels to intervene. ${ }^{63}$ People lost their lives during the course of this incident, not because of being lost at sea, but rather by the manner in which this crisis was handled by the Greek and Turkish authorities in the aftermath of the incident. Moreover overlapping search and rescue regions in other parts of the Mediterranean have also given rise to increased tension, ${ }^{64}$ indicating that this stepping stone for developing cooperation can easily lead to an adverse effect, if not properly managed.

6o Hao, supra note 52, at 244-245.

61 S.K. Kim, Korean Peninsula Maritime Issues, 41 Ocean Development and InternaTIONAL LAW 166-185 (2010). See for more recent examples, see Defense Ministry: South Korea Working to Forge Military Cooperation Pact with China, Indonesia Katakami, 21 May 2012, available at http://indonesiakatakami.wordpress.com/2012/05/21/defense-ministry -south-korea-working-to-forge-military-cooperation-pact-with-china, mentioning such joint exercises between China and the Republic of Korea, and B. Kligner, Washington Should Urge Greater South Korean-Japanese Military and Diplomatic Cooperation, The Heritag E Foundation, 24 September 2012, available at http://www.heritage.org/research/reports/2012/og/washington-should-urge-greater-south-korean-japanese-military-and -diplomatic-cooperation, mentioning joint exercises between Japan, the Republic of Korea and the United States in 2012.

62 For more background on this crisis, see for instance M. Pratt and C. Schofield, The Imia/ Kardak Rocks Dispute in the Aegean Sea, 4 Boundary and Security Bulletin 62-69 (1996); C.P. Economidès, Les îlots d'Imia dans la Mer Egée: un différend créé par la force, 101 Revue Générale de Droit International Public (1997); and E. Raftopoulos, The Crisis over the Imia Rocks and the Aegean Sea Regime: International Law as a Language of Common Interest, 12 International Journal of Marine and Coastal LaW 427446 (1997).

63 T. Korontzis, The Competence of Hellas on Search and Rescue Items in the Aegean Area, 4 Review of European Studies 89, 90 (2012).

64 S. Trevisanut, Search and Rescue Operations in the Mediterranean: Factor of Cooperation or Conflict?, 25 International Journal of Marine and Coastal LaW 523-542 (2010). 


\section{Conclusions}

Search and rescue could easily become a building block for regional cooperation in the East China Sea because all States are a party to the most relevant international treaties, namely the 1982 Convention and, foremost, the 1979 SAR Convention. ${ }^{65}$ Besides punctual joint exercises at sea, as confidence building measures, ${ }^{66}$ it is submitted that the States surrounding the East China Sea should try to conclude agreements between them clearly dividing their respective fields of operation. Incidents occurring in disputed or overlapping areas can easily deteriorate the general climate between the parties changing what appeared to be a building bloc to foster interstate cooperation into a slippery slope easily leading to an increased interstate animosity instead.

Very often it is thought that search and rescue cooperation is not very well suited in regions, such as the East China Sea, where maritime areas are disputed between the coastal States and established maritime boundaries are rather the exception than the rule. This, however, is not a fatality as illustrated by the recently concluded search and rescue agreement in the Arctic, an area of high tension where much of the maritime boundaries still have to be fixed in a definitive manner. ${ }^{67}$ By means of a few simple lines on the map and a ditto savings clause ${ }^{68}$ the Arctic rim countries were able to enter into a joint legally binding instrument. ${ }^{69}$

65 About the possibilities of search and rescue in southeast Asia generally and recommendations to develop cooperation in this respect, see S. Bateman, J. Ho, and J. Chan, Good Order at Sea in the Southeast Asia, RSIS Policy PAPER 4, 38 and 45-46 (2009), available at http://www.rsis.edu.sg/publications/policy_papers/RSIS_Policy\%2oPaper\%20-\%20 Good\%20Order\%20at\%2oSea_270409.pdf.

66 China and the United States have been using this approach in order to try to alleviate their strained relations at sea. Y. Yi, A PLA Navy Perspective on Maritime Security Cooperation, in China, the United States and 21St Century Sea Power: Defining a Maritime SeCurity Partnership, supra note 52 , at 488, 497.

67 Agreement on Cooperation on Aeronautical and Maritime Search and Rescue in the Arctic. Multilateral, signed on 12 May 2011. As of 7 September 2012 this agreement had not yet entered into force (personal communication to the author by Ambassador A. Vasiliev, one of the two co-chairs that headed this Arctic Council Task Force), available at http://library .arcticportal.org/1474/.

68 Art. 3 (2) reads: "The delimitation of search and rescue regions is not related to and shall not prejudice the delimitation of any boundary between States or their sovereignty, sovereign rights or jurisdiction".

69 This is the first legally-binding instrument adopted under the auspices of the Arctic Council, a high level intergovernmental forum established in 1996, in a region governed primarily by a non-legally binding regime. As stressed by S.M. Kao, N.S. Pearre, and J. Fire- 


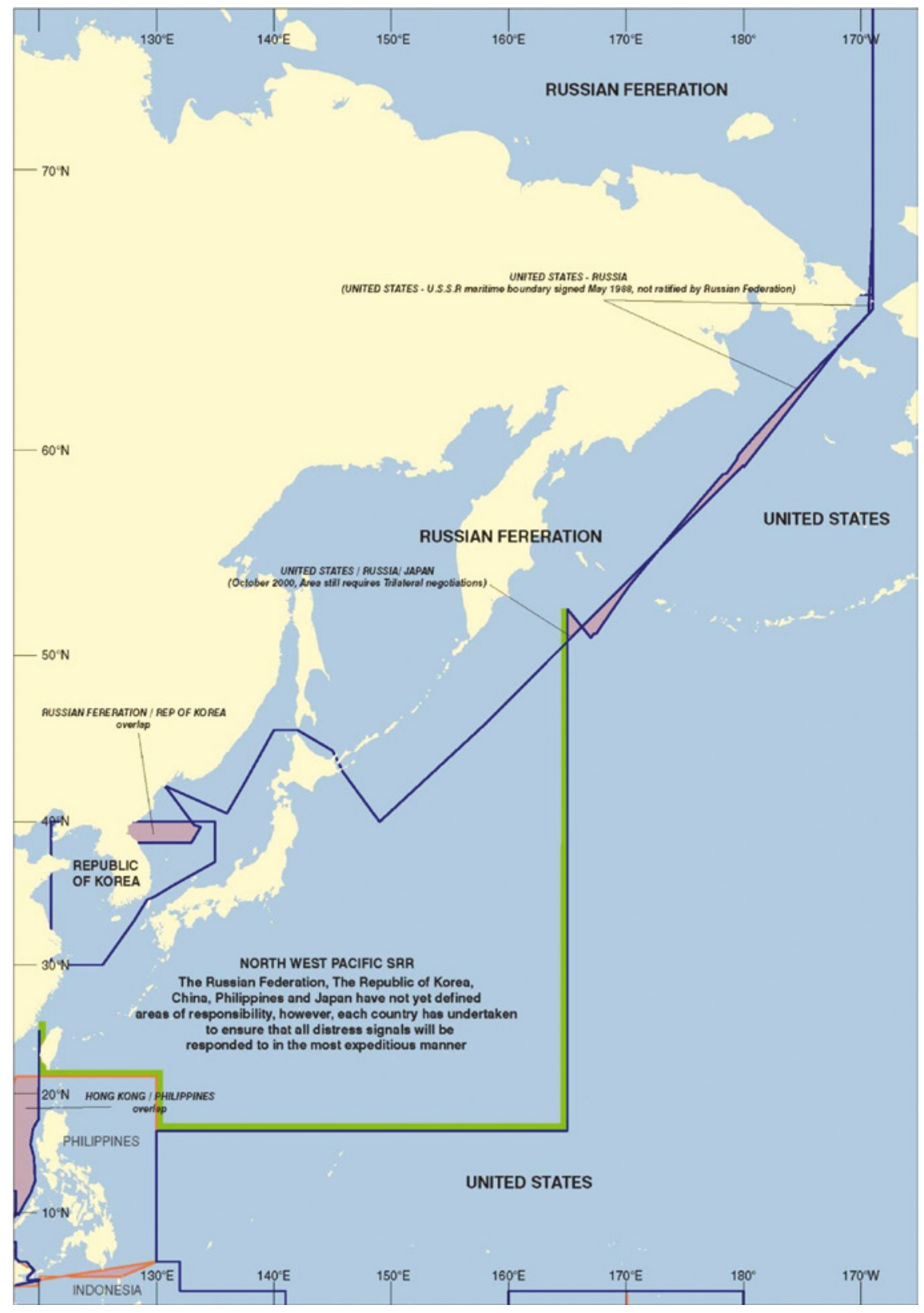

ANNEX 1 IMO Availability of Search and Rescue (SAR) Services IMO Availability of Search and Rescue (SAR) Services

SOURCE: INTERNATIONAL MARITIME ORGANIZATION, AVAILABILITY OF

SEARCH AND RESCUE (SAR) SERVICES, IMO DOC. SAR.8/CIRC.3, 17 JUNE 2011, ANNEX 4, AT 15. 
There is no reason why a similar approach could not be applied to the East China Sea, especially in view of the fact that China, Japan and the Republic of Korea are all legally bound by the 1979 SAR Convention, and consequently also by its Annex containing a similar savings clause. ${ }^{70}$ China moreover repeated this provision, with a specific reference to the exclusive economic zone and the continental shelf, in a declaration made at the time of submitting its instrument of approval to the 1979 SAR Convention. ${ }^{71}$

How Taiwan has to be involved in such closer cooperation is not obvious at present. Different options nevertheless exist, ranging from associate membership in the IMO, which could open the possibility to become a party to the 1979 SAR Convention, to ad hoc solutions worked out by China, Japan and the Republic of Korea, as has happened in the field of fisheries. Leaving Taiwan out of the picture might be a sensible solution in the short run, when countries are trying to overcome their own difficulties first, but seems to be a self-defeating proposition in the longer run.

stone, Adoption of the Arctic Search and Rescue Agreement: A Shift of the Arctic Regime Toward a Hard Law Basis?, 36 MARINe Policy 832, 832 (2012).

$70 \quad 1979$ SAR Convention, supra note 31, Annex, 2.1.7, which reads: "The delimitation of search and rescue regions is not related to and shall not prejudice the delimitation of any boundary between States".

71 At that time China made the following declaration: "The delimitation of search and rescue regions, as stipulated in the Annex to the Convention 2.1.7, is not related to and shall not prejudice the delimitation of any boundary between States, either is not related to and shall not prejudice the delimitation of any exclusive economic zone and continental shelf between States". Available at http://www.imo.org/About/Conventions/StatusOf Conventions/Documents/Status\%20-\%202012.pdf. 